\title{
КЛІНІКО-ПАТОГЕНЕТИЧНІ ОСОБЛИВОСТІ МЕТАБОЛІЧНОГО СИНДРОМУ В ЗАГАЛЬНІЙ ЛІКАРСЬКІЙ ПРАКТИЦІ
}

\author{
ФН. І. Корильчук, Б. Т. Корильчук
}

ДВНз «Тернопільський державний медичний університет імені І. Я. Горбачевського мОз України»

РЕЗюМЕ. Метаболічний синдром на сьогодні $\epsilon$ актуальною медико-соціальною проблемою, до якої прикута увага широкого кола спеціалістів: ендокринологів, кардіологів, гастроентерологів, ревматологів, гінекологів, урологів, сімейних лікарів та педіатрів. Експерти ВООЗ характеризують метаболічний синдром як пандемію XXI століття. В даній роботі проведено аналіз наукових праць вітчизняних та зарубіжних учених, що формують поняття «метаболічного синдрому». Показано нагромаджені фундаментальні знання та клінічні спостереження, що дають можливість глибоко проаналізувати етіологію та клініко-патогенез, перебіг, прогресування та наслідки метаболічного синдрому. Актуальність проблеми зумовлена не тільки його значною поширеністю, а й вираженим помолодшанням недуги, негативним впливом на якість і тривалість життя, істотним збільшенням ризику серцево-судинних катастроф. В Україні летальність від атерогенних кардіоваскулярних захворювань посідає одне з перших місць у структурі загальної смертності населення. Наявність метаболічного синдрому в 3-6 разів підвищує ризик розвитку серцево-судинних ускладнень і $\epsilon$ важким економічним тягарем систем охорони здоров'я в Україні та світі. У таких умовах метаболічний синдром, який поєднує одразу декілька чинників високого судинного ризику, не може залишитися без уваги фахівців. Актуальність проблеми зумовлена й тим, що цей стан $\epsilon$ зворотним, тобто при відповідному лікуванні можна домогтися зникнення чи бодай зменшення виразності основних його проявів. Пацієнт з метаболічним синдромом - це хворий з множинною поєднаною патологією, у якого, поряд з серцевосудинними проявами, наявні захворювання печінки, жовчовивідних шляхів, виражені зміни ліпідного та вуглеводного обмінів, наявні проблеми із суглобами та вагою тощо. Хворі на метаболічний синдром найчастіше $є$ пацієнтами загальної лікарської практики, проте доволі часто не всі складові синдрому привертають увагу лікаря, що призводить до однобічного лікування.

КЛючОВІ СлОВА: метаболічний синдром; ожиріння; клініко-патогенетичні особливості.

Вступ. Метаболічний синдром (МС) - сукупність генетичних, фізіологічних, біохімічних факторів, проявом яких $\epsilon$ розвиток інсулінорезистентності (IP), дисліпідемії, вісцерального ожиріння, артеріальної гіпертензії (АГ), гіперкоагуляційного стану, ендотеліальної дисфункції, гіперурикемії [15].

Дослідники завжди зосереджували свою увагу на тому, що особи, які страждають на ожиріння, мають одночасно проблему з підвищеним артеріальним тиском (АТ), порушенням ліпідного, вуглеводного, часто пуринового обмінів $[2,15,21$, $25,31]$. На це поєднання вперше звернув увагу вчений Г. Ф. Ланг у 1922 році $[16,24]$. Згодом, В 1923 р., ці ж порушення описав шведський вчений Е. Кюлін [15]. У 1926 р. А. Л. М'ясников і Д. М. Гротель вказали на часте поєднання гіперхолестеринемії, гіперурикемії з ожирінням та АГ [16]. у 1931 р. австрійські вчені В. Фальта та Р. Бюллер звернули увагу на існування інсуліночутливих та інсулінорезистентних форм цукрового діабету (ЦД). Британський учений Г. П. Хімсуорт запропонував навантажувальний тест, що вказував на виражену резистентність до інсуліну у осіб з надлишковою вагою. У 1945 році в клініці Г. Ф. Ланга його співробітники Н. А. Голубєва та Л. А. Павлов-
Ська, при визначенні толерантності до глюкози в хворих з АГ, встановили патологічні глікемічні криві у $30 \%$ обстежених, а в 39 \% виявили ЦД 2 типу $[4,16]$. У 1947 р. в наукових роботах Дж. Ваг, описуючи типи відкладання жиру, звернув увагу на те, що андроїдний тип ожиріння частіше, ніж геноїдний, поєднується з ЦД, ішемічною хворобою серця (IXC) та подагрою $[16,32]$. Клініцист Е. М. Тарєєв у 1948 р. у наукових роботах зауважив, що гіпертонія найбільше асоціюється з ожирінням, порушенням білкового обміну, наростанням холестерину, сечової кислоти тощо [16]. В 19601965 рр. Р. Ялоу і С. Берсон довели (розробляючи радіоімунологічне визначення гормонів), що ожиріння поєднується з гіперінсулінемією (ГІ) та IP, й висловили ідею про те, що саме ожиріння, що поєднується з ЦД чи без нього, є причиною IP $[16,20]$.

Термін «метаболічний синдром» у 1980 р. запропонували німецькі вчені М. Ганефельд і В. Леонгардт. Існувало до 20 різних його назв $[2,4,21$, $26,28]$ та понад 20 учених претендують на право першості в вивченні цієї проблеми $[2,4,16,30]$. Проте більшість учених визнають, що найвагоміший доробок у вивченні даного синдрому належить вченому Джеральду Рейвену, оскільки його 
Огляди літератури, оригінальні дослідження, погляд на проблему, ювілеї

стаття «The role of insulin resistance in human disease» залишається самою цитованою працею [3, 17, 18, 30]. В 1998 р. ВООЗ рекомендувала до використання європейський термін «метаболічний синдром» [2].

Основна частина. Уявлення про МС підійшли на сьогоднішній день до кризи, через «перевиробництво» безперервно оновлюваної інформації щодо можливих проявів та через відсутність загальноприйнятої доказової концепції патогенезу [16]. Тривають постійні активні дискусії щодо оптимальних критеріїв синдрому, ролі генетичних особливостей у його етіології, патогенетичної ланки, доцільності використання даного діагнозу з метою оцінки ризику серцево-судинних захворювань (ССЗ) та про конституційний характер МС [2, 11, 19, $24,29]$. Проте концепція МС була і залишається дуже корисною для медицини $[17,22,23,26,28]$.

Поширеність МС, за даними науковців, дуже висока, залежить від використовуваних критеріїв і варіює в широкому діапазоні (серед чоловічого населення - від 8 \% в Індії до 25 \% в США, серед жіночого населення - від 7 \% у Франції до 40 \% в Туреччині та 43-46 \% в Ірані) [10]. Науковці зауважують, що понад 35 \% молодого населення західних країн страждають на цю недугу. А беручи до уваги тих, хто старший 50 років - до 44 \% [14]. Найбільша кількість хворих в США (більше 47 млн), частіше це захворювання реєструють у чоловіків, в жінок його частота зростає в менопаузальному періоді $[3,18]$. Проте $\epsilon$ й дані, що МС поширений серед чоловіків у 24 \%, а серед жінок - у 23,4 \% [12]. Серед афроамериканців поширеність МС у жінок більш ніж наполовину вища, ніж у чоловіків, а серед латиноамериканок - на чверть вища, ніж у чоловіків тієї ж раси. В країнах Південної Азії поширеність МС у 2,5 раза вища, ніж в Європі [17]. У Великобританії повний МС виявляють у 50 \% хворих на ожиріння чоловіків. У Швейцарії та Фінляндії МС без порушень вуглеводного обміну виявляють у $10 \%$ жінок та у $15 \%$ чоловіків, гіперглікемію натще діагностують у $42 \%$ чоловіків та у 64 \% жінок, ЦД - у 78 \% жінок та у 84 \% чоловіків. В європейських країнах МС виявляють у 14-15 \% обстежених в віці 40-60 років $[10,12]$. Всього в світі більше 310 млн осіб з МС, і їх кількість зростає. Загалом у світі поширеність МС складає 3040 \% серед осіб середнього та старшого віку [12, $18,23,26,28]$.

МС - одна з найзагадковіших і найсуперечливіших проблем сучасної медицини [5, 13, 17, 19, 27]. Противники концепції МС підкреслюють двоякість і нечіткість діагностичних критеріїв, які використовуються в визначенні МС $[12,17,27]$. Проте у численних працях показано виняткову значущість МС для прогнозування ССЗ та ЦД 2 типу [13,
$14,17,25]$. Так, наявність МС, за різними джерелами, у 3-6 разів підвищує ризик розвитку серцевосудинних ускладнень. У пацієнтів з МС приблизно в 4 рази зростає частота розвитку фатальних серцево-судинних захворювань і в 3-5 раз - ЦД 2 типу $[10,13,14,24]$. У дослідженнях Three-City Study було продемонстровано, що МС підвищує ризик CС3 на $80 \%$. У дослідженні BOTMAStudy наявність MC підвищувала ризик розвитку IXC в 2,96 раза, IM - в 2,63 раза, інсульту - в 2,27 раза [6]. У дослідженні San Antonio Heart Study ЦД 2 типу виявлено більше ніж у 50 \% осіб з МС впродовж 7 років спостереження [16]. Згідно з даними Фремінгемського дослідження, на кожні 4,5 кг маси тіла систолічний артеріальний тиск підвищується на 4,4 та 4,2 мм рт. ст. у чоловіків та жінок відповідно [14]. Кожен компонент МС сам по собі $є$ встановленим фактором серцево-судинного ризику, а при МС ці фактори не просто сумуються, а значно його збільшують. Окрім того, є дослідження, які свідчать про те, що за минулі десятиліття МС поширився серед дітей та, особливо, підлітків [1, 2, $8,10,26]$. Окрім того, порушення, що об'єднані в рамку МС, тривало перебігають безсимптомно, з початком формування в підлітковому і юнацькому віці, задовго до маніфестації ЦД 2 типу, АГ, атеросклеротичних проявів [2, 15, 29, 32, 33]. У квітні 2005 р. Міжнародна федерація з діабету визначила єдині критерії встановлення діагнозу МС. Хоча серед науковців тривають дискусії стосовно «повного» чи «неповного» $\mathrm{MC}$, що вказує на недооцінювання єдиного механізму, який обумовлює паралельний розвиток всіх каскадів метаболічних розладів при IP [17]. Вчені наводять вагомі аргументи, що при «неповному» МС пацієнти можуть не попасти в поле зору лікарів загальної практики. Наприклад, американські колеги продовжують наполягати, що АО не $є$ обов'язковим компонентом, а три аномальних параметри з п'яти компонентів повинні кваліфікуватися як МС. Частина науковців пропонують розглядати MC «у вузькому розумінні», або в "широкому сенсі слова», беручи до уваги градації компонентів МС [18]. Прихильники ж концепції МС схиляються до створення простих і доступних у клінічній практиці способів оцінки ризику з метою виявлення осіб, що потребують пожиттєвого спостереження, модифікації способу життя, i, при необхідності, - проведення медикаментозної корекції [17, 21, 28, 29].

Патогенез МС на сьогодні залишається до кінця не вивченим та заплутаним $[9,17,30,31]$. Основними факторами його розвитку більшість учених вважають IP і AO [9, 10, 14, 17, 31]. Проте описано і багато інших можливих патофізіологічних механізмів, включаючи порушення функціонування гіпоталамо-гіпофізарно-наднирковозалозної осі, 
Огляди літератури, оригінальні дослідження, погляд на проблему, ювілеї

хронічний стрес, вплив різних пре- і перинатальних факторів, що визначають різні фенотипи, надлишкову продукцію адипоцитами запальних цитокінів та інших біологічно активних субстанцій, порушення згортальної системи крові, хронічну активацію імунної системи тощо $[17,23,25]$.

Ряд вчених уявлення про патогенез вкладають у рамки трьох теорій: глюкоцентричної, ліпоцентричної та ліпокінової [16]. Найпоширеніша та найстарша - глюкоцентрична. Згідно з цією теорією, в основі розвитку як ЦД 2 типу, так і МС лежить єдиний патологічний процес - IP периферійних тканин, наслідком чого $є$ ГІ. IP - це зниження чутливості інсулінових тканин до інсуліну при достатній його концентрації [2, 9, 12, 15]. Інсулін впливає на багато видів обміну речовин в організмі. Він спонукає поступлення глюкози в м'язову, жирову й інші тканини, що регулюють синтез жирних кислот і зберігання глюкози у вигляді глікогену в печінці, перешкоджаючи розщепленню жиру в жировій тканині, активуючи ліпогенез і $\mathrm{Na+-/K+-АТФазу} \mathrm{в} \mathrm{багатьох} \mathrm{клітинах}[12,15]$. В умовах IP виникає "додіабетична» гіперглікемія, яка спонукає глікування білків і відповідні дизрегуляторні та ангіопатичні зміни. Захоплення та окиснення глюкози м'язами знижується, недостатньо гальмується глюконеогенез у печінці. Разом 3 тим, інші органи і тканини можуть стати селективно більш чутливими до тих чи інших ефектів інсуліну. Тобто, ГІ буде спонукати проліферацію судин гладкої мускулатури клітин, дисфункцію ендотелію, гіперактивацію іонообмінних механізмів, що затримують натрій і калій, розвиток ожиріння і гіперлептинемії (ГЛ). Це все запускає патогенетичні механізми формування решти компонентів МС $[11,16]$. За даними вчених, ступінь IP прямо пропорційний числу факторів ризику $[9,11,20,22,24]$.

Згідно з ліпоцентричною теорією, основну роль у розвитку МС відіграє абдомінально-вісцеральна жирова тканина. Андроїдне ожиріння розглядають як «генератор» і один з основних компонентів МС $[6,9,11,16,33]$. Вчені зауважують, що у 88 \% обстежених, незалежно від ступеня андроїдного ожиріння, $\epsilon$ IP, при гіноїдному - лише в 32\%, причому в основному при III-VI ступенях ожиріння. Основною ланкою $M C \in$ надлишок жиру, що підвищує можливості ліпоцитів з його безпечного зберігання. Це викликає "викид" ліпідів за межі малих ліпоцитів підшкірного жиру і вичерпання можливостей їх проліферації. Ліпогенез викликає їх гіпертрофію, а надалі, у міру вичерпання резервів депонуючої функції підшкірної жирової тканини, жир переміщується в абдомінальні ліпоцити [9]. Суттєвою ланкою патогенезу MC, пов'язаною з метаболічною роллю вісцерального жиру, $є$ надлишок ВЖК у крові, які з'являються в результаті вивільнення їх з ліпоцитів за допомогою гормоночутливої ліпази і через вплив ліпопротеїнової ліпази на ендотелій капілярів легень, серця та інших органів. Надлишок ВЖК знижує чутливість печінки та інших тканин до інсуліну Послідовність процесів, на погляд науковців, така: паралельно посиленню обміну/ окиснення ВЖК збільшується швидкість окиснення ліпідів; збільшення окиснення ВЖК проходить за одночасного і паралельного зниження окиснення, а, ймовірно, і запасання глюкози, а також порушення опосередкованого інсуліном пригнічення продукції глюкози печінкою; у міру погіршення толерантності до глюкози, ліпідів окиснюється все більше, а глюкози окиснюється і накопичується в вигляді глікогену все менше; одночасно погіршується чутливість печінки до інсуліну. Відомо, що абдомінальний жир (жир великого і малого сальника і брижі) легко піддається ліполізу [9]. Адипоцити вісцеральної жирової тканини декретують ВЖК безпосередньо у ворітну вену печінки, де ці кислоти повинні утилізуватися. Перший шлях їх утилізації - перетворення нестерифікованих жирних кислот у глюкозу через процеси глюконеогенезу. В результаті цього печінка секретує в кровотік надлишкову кількість глюкози, внаслідок чого виникає гіперглікемія, що спонукає зниження видалення інсуліну печінкою з кровотоку, а це викликає розвиток ГІ. Поряд з цим, надлишок глюкози в крові спонукає IP. Другий шлях утилізації нестерифікованих жирних кислот - це синтез ТГ. Науковці зауважують, що при МС у крові відмічається тригліцеридемія через просочування тригліцеридів із жирової тканини. За цих умов печінка переповнюється ліпідами і починає синтезувати велику кількість лПДНЩ, які перетворюються в ЛПнЩ або руйнуються. ЛПДНЩ утворюються в печінці і $\epsilon$ основною транспортною формою ендогенних ТГ, що синтезуються у печінці. ЛПнЩ легко піддаються різним модифікаціям, а саме, окиснюються під впливом вільних радикалів. Окиснення ЛПНЩ є провідним фактором розвитку атеросклерозу. Надлишки ж холестерину, як відомо, видаляються з судинної стінки за допомогою лПВЩ. ЛПВЩ синтезуються в печінці і кишечнику, містять ефіри холестерину та фосфоліпіди і виконують функцію видалення холестерину з тканин. ЛПВЩ - це антиатерогенні ліпопротеїди. При інсулінемії в печінці активується фермент ліпаза, яка розщеплює лПВЩ, а зниження ЛПВЩ також $\epsilon$ запорукою розвитку атеросклерозу. Розвиток атеросклерозу при ГІ посилюється ще й тому, що інсулін посилює розмноження гладком'язових клітин і фібробластів, спонукає захоплення ЛПНЩ і синтез ендогенного холестерину в клітинах судинної стінки. 
Огляди літератури, оригінальні дослідження, погляд на проблему, ювілеї

Ліпокінова теорія МС пропагує, що основні складові МС формує не стільки субстратно-енергетична роль продуктів ліпоцитів, скільки інформаційний вплив на організм ліпоцитарних сигнальних молекул. Жирова тканина не лише $\epsilon$ пасивним джерелом енергії, а й виробляє регуляторні білки (лептин, адипонектин, резистин, фактор некрозу пухлини альфа (ФНП-а), прокоагуляційний агент, адипофілін, дипсин, агуті білок тощо), тобто $\epsilon$ активним ендокринним органом $[5,6,16]$. Лептин це гормон, що продукується жировими клітинами і циркулює в крові у вільній та зв'язаній формах [15]. Рівень лептину відображає сумарний енергетичний резерв жирової тканини і може змінюватися при короткочасних порушеннях енергетичного балансу та змінах концентрації деяких цитокінів і гормонів, які також циркулюють у крові. Лептин, що декретується переважно адипоцитами, діє на рівні гіпоталамуса, регулюючи харчову поведінку і активність симпатичної нервової системи, а також низки ендокринних функцій. Багато досліджень вказують, що в печінці він може гальмувати дію інсуліну на глюконеогенез шляхом впливу на активність фосфоенолпіруваткарбоксикінази - ферменту, що обмежує швидкість глюконеогенезу. В жировій тканині лептин може пригнічувати стимульований інсуліном транспорт глюкози (аутокринна дія). Науковці вказують на незалежну продукцію лептину, ГI та IP. Проте $\epsilon$ й твердження про те, що лептин здатний підвищувати поглинання глюкози жировими клітинами. На рівні гіпоталамуса лептин впливає на продукцію й інших нейропептидів, що беруть участь у регуляції апетиту (меланоцит-стимулювальний гормон та агуті-зв'язуючий білок), проопіомеланокортину і кокаїн/амфетамінрегулювального пептиду. У наукових джерелах вказують на чинники зовнішнього середовища, які впливають на рівень лептину більшою мірою, ніж генетичні чинники. Продукція лептину зростає при інфекції, ендотоксикозах і стимулюється цитокінами. Важливим регулятором секреції лептину вважають ГІ, яка розвивається при МС. Адипоцити виробляють лептин у відповідь на підвищення рівня інсуліну після їди у здорових людей та у хворих на МС. Лептин активує вихід калію з клітин, сприяє гіперполяризації мембран та пригнічує реакцію смакових рецепторів на солодкі подразники. У контексті патогенезу МС - гіперлептинемія завжди супроводжує МС. Підвищення рівня лептину негативно впливає на стан та функціонування багатьох органів $[5,14]$. Гіперлептинемію пов'язують також з патогенезом гіпертрофії міокарда, XCH, хронічної хвороби нирок тощо. Фактор некрозу пухлини альфа (кахексин) також має важливу роль в патогенезі MC $[5,9,15]$, оскільки його продукція зростає при IP і АО. Ліпоцити при пошкодженні декретують кахексин разом з іншими прозапальними ліпокінами - ІЛ-6, ІЛ-8 та ІЛ-1, що веде до наростання в подальшому С-реактивного білка і зсуву співвідношення гемостатичних та антигемостатичних механізмів у тромбофілійну, прокоагуляційну сторону.

На сьогодні немає єдиної думки про першопричину виникнення МС, невідомо, чи цей стан запрограмований виключно генетично, чи розвивається через фактори навколишнього середовища $[2,13,24]$. Та за роки вивчення МС інтерес до нього не згасає $[11,13,26,30]$. Провідні міжнародні організації з вивчення МС постійно оновлюють визначення, критерії MC $[13,15,25]$, проте експерти ВООЗ зауважують, що це питання ще не вивчено. МС можна розглядати як міждисциплінарну проблему, оскільки розвивається ко- та поліморбідна патологія за участю МС та між його компонентами $\epsilon$ причинно-наслідковий зв'язок $[11,13,15,25,33]$. Пацієнти з ЦД 2 типу, надмірною вагою чи ожирінням (особливо абдомінальним), особи з IXC та АГ, жировою дистрофією печінки - це групи хворих, у яких поширеність МС $\epsilon$ найвищою [13]. При подагрі, полікістозі яєчників, зниженні функції щитоподібної залози, при еректильній дисфункції, циркуляторній енцефалопатії, депресії, остеопорозі виявлено феномен взаємного обтяження коморбідного процесу на фоні MC $[9,13,22,33]$. Знання сучасних критеріїв діагностики МС, цільових рівнів АТ, показників ліпідів та глюкози крові, гормональної панелі, повинні стати базовими як для ендокринологів, кардіологів, так і для лікарів загальної практики.

Висновки. Подальше вивчення клініко-патогенетчних особливостей МС дасть пояснення та можливість раннього виявлення, своєчасної профілактики, раннього лікування МС у загальній лікарській практиці. Раннє реагування на МС лікарями загальної практики прямо пов'язано з відтермінуванням ЦД 2 типу, серцево-судинних захворювань, інвалідизації чи смертності.

Перспективи подальших досліджень полягають у вивченні нових методів ранньої діагностики, стратифікації факторів ризику, що поліпшить боротьбу з ними та лікування МС.

\section{ЛІТЕРАТУРA}

1. Бабінець Л. С. Актуальність вікового аспекту клінічного перебігу і ведення хворих на хронічний панкреатит / Л. С. Бабінець, Н. О. Шевченко // Здобутки клінічної і експериментальної медицини. - 2017. - № 4. - С. 5-11.

2. Байдурин С. А. Метаболический синдром: особенности патогенеза, принципы диагностики, профилактики и лечения/С. А.Байдурин//Медицина.-2013.№ 1. - С. 8-13. 
Огляди літератури, оригінальні дослідження, погляд на проблему, ювілеї

3. Бродська А. Ю. Абдомінально-вісцеральне ожиріння як ключова ланка розвитку метаболічного синдрому у жінок в пременопаузі / А. Ю. Бродська // Природничий альманах. - 2010. - № 14. - С. 25-31.

4. Бутрова С. А. Метаболический синдром: патогенез, клиника, диагностика, подходы к лечению / С. А. Бутрова // Русский медицинский журнал. - 2001. № 2. - C. 56-60.

5. Гинзбург М. М. Ожирение и метаболический синдром. Влияние на состояние здоровья, профилактика и лечение. - Самара : Парус, 2000. - 160 с.

6. Донцов А. В. Связь абдоминального ожирения с метаболическими и гормональными нарушениями у больных ИБС / А. В. Донцов // Научные ведомости. Серия: Медицина. Фармация. - 2013. - № 11 (154), Выпуск 22. - С. 80-83.

7. Заяць М. М. Клініко-економічний аналіз як складова оптимізації фармакотерапії метаболічного синдрому / М. М. Заяць, А. Б. Зіменковський // Запорожский медицинский журнал. - 2013. - № 4 (79). - С. 10-12.

8. Клініко-біохімічні маркери метаболічного синдрому в дітей та підлітків / І. А. Зорій, С. В. Білецький, Н. М. Шевчук, Т. М. Крецун // Буковинський медичний вісник. - 2007. - Т. 11, № 2. - С. 40-44.

9. Коваленко В. М. Метаболічний синдром: механізми розвитку, значення як фактора серцево-судинного ризику, принципи діагностики та лікування / В. М. Коваленко, Т. В. Талаєва, А. С. Козлюк // Український кардіологічний журнал. - 2013. - № 5. - С. 80-87.

10. Метаболический синдром у лиц разного пола с избыточной массой тела и ожирением / М. А. Когай, Ю. В. Лутов, Б. Б. Пинхасов [и др.] // Вестник новых медицинских техноголий. - 2008. - Т. XV, № 1. - С. 141-143.

11. Корильчук Н. І. Комплексний підхід до корекції гіперінсулінемії, гіперлептинемії та інсулінорезистентності в хворих з абдомінальним типом ожиріння / Н. І. Корильчук // Вісник наукових досліджень. - 2007. № 4. - С. 44-46.

12. Красюк О. А. Метаболічний синдром в практиці клініциста / О. А. Красюк // Військова медицина України. - 2008. - Т. 8, № 4. - С. 105-110.

13. Лящук Р. П. Метаболічний синдром як міждисциплінарна проблема / Р. П. Лящук, П. М. Лящук // Міжнародний ендокринологічний журнал. - 2017. - № 7. C. 499-502.

14. Метаболічний синдром - деякі особливості патогенезу та його вплив на розвиток артеріальної гіпертензії / Г. В. Мартинюк, Н. Т. Скорейко, Р. С. Скорейко, С. Ч. Скорейко // Буковинський медичний вісник. 2016. - T. 20, № 2. - С. 85-87.

15. Мельник А. А. Метаболический синдром и риск хронической болезни почек / А. А. Мельник // Почки. 2017. - № 2. - С. 80-90.

16. Классические и современные представления о метаболическом синдроме / Ю. И. Строев, М.В.Цой, Л. П. Чурилов, А. Н. Шишкин // Вестник Санкт-Петербургского университета. - 2007. - Сер. 11, Вып. 1. - С. 3-13.

17. Учамприна В. А Метаболический синдром: аргументы «за» и «против» / В. А. Учамприна, Т. И. Ро- манцова, М. Ф. Калашникова // Ожирение и метаболизм. - 2012. - № 2. - С. 17-27.

18. Метаболический синдром: сложные и нерешенные проблемы / Г. А. Чумакова, Н. Г. Веселовская, О.В.Гриценко, А. В. Отт // Российский кардиологический журнал. - 2014. - № 3. - С. 63-71.

19. NCEP-defined metabolic syndrome, diabetes, and prevalence of coronary heart disease among NHANES III participants age 50 years and older / C. M. Alexander, P. B. Landsman, S. M. Teutsch, S. M. Haffner // Diabetes. 2003. - Vol. 52 (5). - P. 1210-1214.

20. Cefalu W. T. Insulin resistance and cardiometabolic risk // Atlas of cardiometabolic risk / W. T. Cefalua, Ch. P. Cannon. - N-Y, London, 2007. - P. 27-37.

21. Day C. Diagnostic definitions - metabolic syndrome / C. Day // Br. J. Diab. Vasc. Dis. - 2005. - Vol. 5. - P. 115-118.

22. Despres J. P. Metabolic syndrome: The dysmetabolic state of dysfunctional adipose tissue and insulin resisyance / J. P. Despres, H. B. Brewer // Eur. Heart J. - 2008. Vol. 10 (Suppl. B). - P. 1-3.

23. Fatty liver and the metabolic syndrome among Shanghai adults / J. G. Fan, J. Zhu, X. J. Li [et al.] // J. Gastroenterol. Hepatol. - 2005. - Vol. 20, No. 12. - P. 1825-1832.

24. Intraabdominal adiposity, abdominal obesity, and cardiometabolic risk/E. Ferrannini, A. M. Sironi, P. Iozzo, A. Gastaldelli // Eur. Heart J. - 2008. - Vol. 10 (Suppl. B). - P. 4-10.

25. Ford E. S. Risks for all-cause mortality, cardiovascular disease, and diabetes associated with the metabolic syndrome: a summary of evidence / E. S. Ford // Diabetes Care. - 2005. - Vol. 28. - P. 1769-1778.

26. Definition of metabolic syndrome: Report of the National Heart, Lung, and Blood Institute. American Heart Association conference on scientific issues related to definition / S. M. Grundy, H. B. Brewer, J. I. Cleeman [et al.] // Circulation. - 2004. - Vol. 109 (3). - P. 433-438.

27. The Metabolic syndrome: time for a critical appraisal / R. Kahn, J. Buse, E. Ferrannini, M. Stern // Diabetes Care. - 2005. - No. 28. - P. 2289-2304.

28. Matfin G. Challenges in developing therapies for the metabolic syndrome / G. Matfin // Br. J. Diabetes Vasc. Dis. - 2007. - Vol. 7, No. 4. - P. 152-156.

29. Panchal S. K. Quercetin ameliorates cardiovascular, hepatic, and metabolic changes in diet-induced metabolic syndrome in rats / S. K. Panchal, H. Poudyal, L. Brown // J. Nutr. - 2012. - Vol. 142 (6). - P. 1026-1032.

30. Reaven G. M. Banting lecture: Role of insulin resistance in human disease / G. M. Reaven // Diabetes. - 1988. Vol. 37. - P. 1595-1607.

31. Reaven G. M. Insulin resistance, cardiovascular disease, and the metabolic syndrome / G. M. Reaven // Diabetes. Care. - 2004. - Vol. 27. - P. 1011-1012.

32. Reaven G. M. Insulin resistance/compensatory hyperinsulineamia, essential hypertension, and cardiovascular disease / G. M. Reaven // J. Clin. Endocrinol. Metabol. 2003. - Vol. 88, No. 6. - P. 2399-2403.

33. Shea S. Obesity, fasting plasma insulin, and C-reactive protein levels in healthy children / S. Shea, E. Aymong, P. Zybert // Obes. Res. - 2003. - Vol. 11. - P. 95-103. 


\section{Огляди літератури, оригінальні дослідження, погляд на проблему, ювілеї \\ REFERENCES}

1. Babinets, L.S., Shevchenko, N.O. (2017). Aktualnist vikovoho aspektu klinichnoho perebihu i vedennia khvorykh na khronichnyi pankreatyt [Actuality of the age-related aspect of clinical course and management of patients with chronic pancreatitis]. Zdobutky klinichnoi i eksperymentalnoi medytsyny - Achievements of Clinical and Experimental Medicine, 4, 5-11 [in Ukrainian].

2. Baydurin, S.A. (2013). Metabolicheskiy sindrom: osobennosti patogeneza, printsipy diagnostiki, profilaktiki i lecheniya [Metabolic syndrome: features of pathogenesis, principles of diagnosis, prevention and treatment]. Meditsina-Medicine, 1, 8-13 [in Russian].

3. Brodska, A.lu. (2010). Abdominalno-vistseralne ozhyrinnia yak kliuchova lanka rozvytku metabolichnoho syndromu u zhinok v pre menopauzi [Abdominal-visceral obesity as a key link in the development of metabolic syndrome in premenopausal women]. Pryrodnychyi almanakh - Natural Almanac, 14, 25-31 [in Ukrainian].

4. Butrova, S.A. (2001). Metabolicheskiy sindrom: patogenez, klinika, diagnostika, podkhody k lecheniyu [Metabolic syndrome: pathogenesis, clinic, diagnosis, approaches to treatment]. Russkiy meditsinskiy zhurnal Russian Medical Journal, 2, 56-60 [in Russian].

5. Ginzburg, M.M. (2000). Ozhirenie i metabolicheskiy sindrom. Vliyanie na sostoyanie zdorovya, profilaktika $i$ lechenie [Ozhirenie i metabolicheskiy sindrom. Vliyanie na sostoyanie zdorovya, profilaktika i lechenie]. Samara: Parus [in Russian].

6. Dontsov, A.V. (2013). Svyaz abdominalnogo ozhireniya $s$ metabolicheskimi i gormonalnymi narusheniyami u bolnykh IBS [The connection of abdominal obesity with metabolic and hormonal disorders in patients with IHD]. Nauchnye vedomosti - Seriya Meditsina. Farmatsiya - Scientific Bulletin - Series Medicine. Pharmacy, 11, 80-83 [in Russian].

7. Zaiats, M.M., \& Zimenkovskyi, A.B. (2013). Klinikoekonomichnyi analiz yak skladova optymizatsii farmakoterapii metabolichnoho syndromu [Clinical and economic analysis as a component of optimization of pharmacotherapy of metabolic syndrome]. Zaporozhskiy meditsynskiy zhurnal-Zaporizhzhia Medical Journal, 4, 10-12 [in Ukrainian].

8. Zorii, I.A., Biletskyi, S.V., Shevchuk, N.M., \& Kretsu, T.M. (2007). Kliniko-biokhimichni markery metabolichnoho syndromu $v$ ditei ta pidlitkiv [Clinical and biochemical markers of metabolic syndrome in children and adolescents]. Bukovynskyi medychnyi visnyk - Bukovyna Medical Bulletin, 2, 40-44[in Ukrainian].

9. Kovalenko, V.M., Talaieva, T.V., \& Kozliuk, A.S. (2013). Metabolichnyi syndrom: mekhanizmy rozvytku, znachennia yak faktora sertsevo-sudynnoho ryzyku, pryntsypy diahnostyky ta likuvannia [Metabolic syndrome: mechanisms of development, significance as a factor of cardiovascular risk, principles of diagnosis and treatment]. Ukrainskyi kardiolohichnyi zhurnal - Ukrainian Cardiological Journal, 5, 80-87 [in Ukrainian].

10. Kogay, M.A., Lutov, Yu.V., Pingasov, B.B., Selyatitskaya, V.G., Shorin, Yu.P. (2008). Metabolicheskiy sindrom u lits raznogo pola s izbytochnoy massoy tela i ozhireniem [Metabolic syndrome in persons of different sex with excessive body weight and obesity]. Vestnik novykh meditsinskikh tekhnologiy - Bulletin of New Medical
Technologists, 1, 141-143 [in Russian].

11. Korylchuk, N.I. (2007). Kompleksnyi pidkhid do korektsii hiperinsulinemii, hiperleptynemii ta insulinorezystentnosti v khvorykh $\mathrm{z}$ abdominalnym typom ozhyrinnia [Comprehensive approach to the correction of hyperinsulinemia, hyperleptinemia and insulin resistance in patients with abdominal type of obesity]. Visnyk naukovykh doslidzhen-Bulletin of Scientific Researches, 4, 44-46 [in Ukrainian].

12. Liashhuk R.P., \& Liashhuk P.M. (2017). Metabolichnyi syndrom yak mizhdystsyplinarna problema [Metabolic syndrome as an interdisciplinary problem.]. Mizhnarodnyi endokrynolohichnyi zhurnal - International Endocrinology Journal, 7, 499-502 [in Ukrainian].

13. Krasiuk, O.A. (2008). Metabolichnyi syndrom v praktytsi klinitsysta [Metabolic syndrome in the practice of a clinician]. Viiskova medytsyna Ukrainy-Military Medicine of Ukraine, 4, 105-110 [in Ukrainian].

14. Martyniuk, H.V., Skoreiko, N.T., Skoreiko, R.S., \& Skoreiko, S.Ch. (2016). Metabolichnyi syndrom - deiaki osoblyvosti patohenezu ta yoho vplyv na rozvytok arterialnoi hipertenzii [Metabolic syndrome - some features of pathogenesis and its influence on the development of arterial hypertension]. Bukovynskyi medychnyi visnyk Bukovyna Medical Bulletin, 2, 85-87 [in Ukrainian].

15. Melnik, A.A. (2017). Metabolicheskiy sindrom i risk khronicheskoy bolezni pochek [Metabolic syndrome and the risk of chronic kidney disease]. Pochki-Kidneys, 2, 80-90 [in Russian].

16. Stroev, Yu.I., Tsoy, M.V., Churilov, L.P., \& Shishkin, A.N. (2007). Klassicheskie i sovremennye predstavleniya o metabolicheskom sindrome [Classical and modern notions about metabolic syndrome]. Vestnik Sankt-Petersburgskogo universiteta - Bulletin of Saint-Petersburg University, 3-13 [in Russian].

17. Uchamprina, V.A., Romancova, T.I., Kalashnikova, M.F. (2012). Metabolicheskij sindrom: argumenty "za" i "protiv" [Metabolic syndrome: arguments "for" and "against"]. Ozhirenie i metabolizm - Obesity and Metabolism, 2, 17-27 [in Russian].

18. CHumakova, G.A., Veselovskaya, N.G., Gricenko, O.V. Ott, A.V. (2014). Metabolicheskij sindrom: slozhnye i nereshennye problemy [Metabolic syndrome: complex and unresolved problems]. Rossiyskiy kardiologicheskiy zhurnal The Russian Cardiology Journal, 3, 63-71 [in Russian].

19. Alexander, C.M., Landsman, P.B., Teutsch, S.M., \& Haffner, S.M. (2003). NCEP-defined metabolic syndrome, diabetes, and prevalence of coronary heart disease among NHANES III participants age 50 years and older. Diabetes, 52,1210-1214

20. Cefalu, W.T. Cannon, Ch.P. (2007). Insulin resistance and cardiometabolic risk. Atlas of Cardiometabolic Risk, 27-37.

21. Day, C. (2005). Diagnostic definitions - metabolic syndrome. Br. J. Diab. Vasc. Dis., 5, 115-118.

22. Despres, J.P., \& Brewer, H.B. (2008). Metabolic syndrome: The dysmetabolic state of dysfunctional adipose tissue and insulin resisyance. Eur. Heart J., 10, 1-3.

23. Fan, J.G., Zhu, J., \& Li, X.J. (2005). Fatti liver and the metabolic syndrome among Shanghai adults. J. Gastroenterol. Hepatol., 12, 1825-1832.

24. Ferrannini, E., Sironi, A.M., lozzo, P., \& Gastaldelli, A. (2008). Intraabdominal adiposity, abdominal obesity, and cardiometabolic risk. Eur. Heart J., 10, 4-10. 
Огляди літератури, оригінальні дослідження, погляд на проблему, ювілеї

25. Ford, E.S. (2005). Risks for all-cause mortality, cardiovascular disease, and diabetes associated with the metabolic syndrome: a summary of evidence. Diabetes Care., 28, 1769-1778.

26. Grundy, S.M., Brewer, H.B. Jr., \& Cleeman, J.I. (2004). Definition of metabolic syndrome: Report of the National Heart, Lung, and Blood Institute. American Heart Association conference on scientific issues related to definition Circulation, 109 (3), 433-438.

27. Kahn, R., Buse, J., Ferrannini, E., \& Stern, M. (2005) The Metabolic syndrome: time for a critical appraisal. Diabetes Care, 28, 2289-2304.

28. Matfin, G. (2007). Challenges in developing therapies for the metabolic syndrome. Br. J. Diabetes Vasc. Dis., 4, 152-156.
29. Panchal, S.K., Poudyal, H., \& Brown, L. (2012). Quercetin ameliorates cardiovascular, hepatic, and metabolic changes in diet-induced metabolic syndrome in rats. J. Nutr., 142 (6), 1026-1032.

30. Reaven, G.M. (1988). Banting lecture: Role of insulin resistance in human disease. Diabetes, 37, 1595-1607.

31. Reaven, G.M. (2004). Insulin resistance, cardiovascular disease, and the metabolic syndrome. Diabetes. Care, 27, 1011-1012.

32. Reaven, G.M. (2003). Insulin resistance/compensatory hyperinsulineamia, essential hypertension, and cardiovascular disease. J. Clin. Endocrinol. Metabol., 88, (6), 2399-2403.

33. Shea, S., Aymong, E., \& Zybert, P. (2003). Obesity, fasting plasma insulin, and C-reactive protein levels in healthy children. Obes. Res., 11, 95-103.

\title{
КЛИНИКО-ПАТОГЕНЕТИЧЕСКИЕ ОСОБЕННОСТИ МЕТАБОЛИЧЕСКОГО СИНДРОМА В ОБЩЕЙ ВРАЧЕБНОЙ ПРАКТИКЕ
}

\author{
ОН. И. Корильчук, Б. Т. Корильчук \\ Гвуз «Тернопольский государственный медицинский университет имени И. Я. Горбачевского \\ МОЗ Украины»
}

РЕЗЮМЕ. Метаболический синдром сегодня является актуальной медико-социальной проблемой в мире, К которой приковано внимание широкого круга специалистов: эндокринологов, кардиологов, гастроэнтерологов, ревматологов, гинекологов, урологов, семейных врачей и педиатров. Эксперты ВОЗ характеризуют метаболический синдром как пандемию XXI века. В данной работе проведен анализ работ отечественных и зарубежныX ученых, которые сформировалипонятие «метаболического синдрома». Показаны накопленные фундаментальные знания и клинические наблюдения, которые дают возможность глубоко проанализировать этиологию и клиникопатогенез, течение, прогрессирование и последствия метаболического синдрома. Актуальность проблемы обусловлена не только его значительной распространенностью, но и омоложением болезни, негативным влиянием на качество и продолжительность жизни, существенным увеличением риска сердечно-сосудистых катастроф. В Украине летальность от атерогенных кардиоваскулярных заболеваний занимает одно из первых мест в общей смертности населения. Наличие метаболического синдрома в 3-6 раз повышает риск развития сердечно-сосудистых осложнений и является тяжелым экономическим бременем систем здравоохранения в Украине и мире. В таких условиях метаболический синдром, в понятии которого сочетаются сразу несколько факторов высокого сосудистого риска, не может не привлекать к себе внимания специалистов. Актуальность проблемы обусловлена и тем, что это состояние является оборотным, то есть, при соответствующем лечении, можно добиться исчезновения, или хотя бы уменьшения выраженности основных его проявлений. Пациент с метаболическим синдромом - это больной с множественной сочетанной патологией, у которого, наряду с сердечно-сосудистыми проявлениями, имеются заболевания печени, желчевыводящих путей, изменения липидного и углеводного обменов, проблемы с суставами и весом. Больные метаболическим синдромом чаще всего являются пациентами общей врачебной практики, однако зачастую не все составляющие синдрома привлекают внимание, что приводит к одностороннему лечению.

КЛЮчЕВЫЕ СЛОВА: метаболический синдром; ожирение; клинико-патогенетические особенности.

\section{CLINICAL AND PATHOGENETIC FEATURES OF METABOLIC SYNDROME IN GENERAL DRUG PRACTICE}

\section{@N. I. Korylchuk, B. T. Korylchuk \\ I. Horbachevsky Ternopil State Medical University}

SUMMARY. Metabolic syndrome today is an urgent medical and social problem in the world, which attracts attention of a wide range of specialists: endocrinologists, cardiologists, gastroenterologists, rheumatologists, gynecologists, urologists, family doctors and pediatricians. Experts of WHO characterize the metabolic syndrome as pandemia of the 21st century. In this work, the analysis of scientific sources of own and foreign scientists, which formed the concept of "metabolic syndrome" is given. The accumulated fundamental knowledge and clinical observations are shown, which give an opportunity to deeply analyze the etiology and clinical pathogenesis, course, progression and consequences of 
Огляди літератури, оригінальні дослідження, погляд на проблему, ювілеї

the metabolic syndrome. The urgency of the problem is caused not only by its significant prevalence, but also by the rejuvenation of the disease, the negative impact on quality and life expectancy, a significant increase in the risk of cardiovascular disasters. In Ukraine, mortality from atherogenic cardiovascular diseases is one of the first places in the overall mortality of the population. The presence of a metabolic syndrome increases the risk of developing cardiovascular complications in 3-6 times and is a hard economic burden for health systems in Ukraine and the world. In such conditions, the metabolic syndrome, in the concept of which several factors of high vascular risk are combined at once, can not but attract attention of the specialists. The urgency of the problem is due to the fact that this condition is reversed, that if you pvescribe appropriate treatment, it is possible to achieve disappearance, or at least a decrease in the severity of its main manifestations. A patient with a metabolic syndrome is a patient with multiple associated pathologies, who, along with cardiovascular manifestations, have liver, biliary tract, lipid and carbohydrate metabolism changes, problems with joints and weight. Patients with metabolic syndrome most often are patients of general medical practice, but often, not all components of the syndrome attract attention by masking and further treated unilaterally.

KEY WORDS: metabolic syndrome; obesity; clinical and pathogenetic features. 